\title{
Removal of Lead, Cadmium and Cobalt from Oil Spill Water onto Soursop (Annonamuricata) Peel
}

\author{
M. M. Ndamitso ${ }^{1, ~}$, S. Mustapha ${ }^{1}$, M. B. Etsuyankpa ${ }^{1}$, J. O. Jacob ${ }^{1}$, I. O. Adeshina ${ }^{2}$, L. Ekor ${ }^{1}$ \\ ${ }^{1}$ Department of Chemistry, Federal University of Technology, Minna, Nigeria \\ ${ }^{2}$ Department of Chemistry, Sokoto State University, Sokoto, Nigeria
}

Email address:

Fudabinda@gmail.com (M. M. Ndamitso)

\section{To cite this article:}

M. M. Ndamitso, S. Mustapha, M. B. Etsuyankpa, J. O. Jacob, I. O. Adeshina, L. Ekor. Removal of Lead, Cadmium and Cobalt from Oil Spill Water onto Soursop (Annonamuricata) Peel. Science Journal of Analytical Chemistry. Vol. 4, No. 1, 2016, pp. 7-11. doi: $10.11648 /$ j.sjac.20160401.12

\begin{abstract}
This study was carried out to evaluate the efficiency of metals ( $\mathrm{Pb}, \mathrm{Cd}$ and $\mathrm{Co}$ ) removal from oil spill water using the soursop (Annonamuricata) peels as adsorbent. Batch adsorption experiment was conducted as a function of $\mathrm{pH}$, contact time, adsorbent dosage and particle size. Optimum $\mathrm{pH}$ of removal obtained for $\mathrm{Pb}, \mathrm{Cd}$ and $\mathrm{Co}$ ions were 6,6 and 4 respectively. The kinetic data obtained in this study fitted well to pseudo-second order model. This study showed that soursop peels is a potential biosorbent for the removal of $\mathrm{Pb}, \mathrm{Cd}$ and $\mathrm{Co}$ ions from oil spill water, thus providing a cheap way of safeguarding human health, aquatic lives and soil fertility.
\end{abstract}

Keywords: Soursop, Optimum, Biosorbent, Oil Spill

\section{Introduction}

Oil exploration and production activities have left a severely degraded environment in the Niger Delta region, South-South, Nigeria. The increase in environmental damage has been attributed to the uncontrolled discharge of oil or its by-products including other chemicals and wastes into water. The discharge could occur as a result of equipment failure and operational errors which raise the pollutant levels in water $[1,2]$. Therefore, crude oil extraction and processing not only damage the environment but also adversely affect communities and public health. Pollution of rivers and ponds by oil spills and by-product from extraction, dredging and canalization related to crude oil extraction, lead to loss of aquatic organisms and contamination of drinking water [3, 4].

Extensive increase in level of oil spillage in water systems causes increase in toxic metals such as $\mathrm{Cd}, \mathrm{Cr}, \mathrm{Ni}$ and $\mathrm{Pb}$ which makes water unsuitable for drinking, irrigation and aquatic life [5]. Soils soaked with crude oil immediately drop in their fertility and $\mathrm{pH}$ which promotes environmental degradation thus influencing the solubility and abundance of micro-nutrients [6]. This eventually leads to imbalance of carbon- nitrogen ratio in such oil-soaked soils.

As a result of increasing concern on these toxic heavy metals, a number of technologies have been developed over the years to remove them from wastewater. These include reduction, electrochemical precipitation, chemical precipitation, chemical oxidation-reduction, ultra filtration, ion-exchange, reverse osmosis, solvent extraction, electrodialysis, electrochemical coagulation and evaporation [7]. A survey of the advantages and disadvantages of these techniques shows that reduction-precipitation methods offer economic advantage but the major drawback is huge production of sludge [8]. Thus, the need for an alternative safe and robust economical method for the removal of potentially toxic elements from contaminated water is not only necessity but a priority.

Adsorption technique offers hope due to its simplicity, environmental friendliness, cost-effectiveness and above all, availability of the agricultural wastes. This creates a need for the conversion of agricultural products and wastes to useful inexpensive ion exchange or adsorbent materials which could remove potentially toxic metal ions from wastewater. The idea of using various agricultural products and by-products for the removal of heavy metal from solution has been investigated $[9,10]$. Thus, the use of low cost adsorbents derived from agricultural and industrial solid wastes for wastewater treatment has attracted a vast amount of attention in recent years. These waste materials are underutilized 
although they are readily available. Consequently, the use of these low cost adsorbents forms the main focus of this study. The study is therefore designed to evaluate the adsorption performance of low cost adsorbent soursop (Annonamuricata) peel on the removal of $\mathrm{Pb}, \mathrm{Cd}$ and $\mathrm{Co}$ ions from oil spill water.

\section{Materials and Methods}

\subsection{Sample Collection and Preparation}

The soursop fruits were purchased from Bosso market in Minna Metropolis, Niger State in Nigeria during the dry season. The soursop fruits were mixed together; the edible parts were removed and washed off from the epicarp (peel). The peel was cleaned, washed with deionized water for several times to remove dirt, then dried for second weeks and ground to powder form with mortar and pestle. The ground sample was then filtered with $50 \mu \mathrm{m}$ sieve mesh size to get very fine particle size.

\subsection{Digestion of Oil Spill Water for Analysis}

$10.0 \mathrm{~cm}^{3}$ of the oil spill water was measured into a beaker which was followed by $5.0 \mathrm{~cm}^{3}$ of conc. $\mathrm{HNO}_{3}$ and $2 \mathrm{~cm}^{3}$ of $\mathrm{HCl}$. It was heated to digest the sample to about half of the initial oil spill water measured. $15.0 \mathrm{~cm}^{3}$ of deionized water was added to dilute the digested sample and then filtered. The heavy metals present in the oil spill water sample were analyzed using the atomic-absorption spectrophotometer (Bulk SCIENTIFIC/ Model 210VGP).

\subsection{Batch Adsorption Studies}

Batch biosorption experiments were conducted for each metal by contacting $0.5 \mathrm{~g}$ of adsorbent (ground soursop peel) with $40.0 \mathrm{~cm}^{3}$ of wastewater containing the metal ions of predetermined concentrations at $29^{\circ} \mathrm{C}$ and fixed $\mathrm{pH}$ values. The suspensions were placed on a shaker and agitated at 150 rotations per minute (rpm). All studies were conducted for the interval contact times to achieve equilibrium at initial $\mathrm{pH}$ ranging from 1-8 using either $1.0 \mathrm{M} \mathrm{HCI}$ or $1 \mathrm{M} \mathrm{NaOH}$ to adjust to the desired $\mathrm{pH}$, dosage of the adsorbents $(0.5-2.5 \mathrm{~g})$ and particle sizes of 50,100,150, 200 and $250 \mu \mathrm{m}$. At the end, the suspensions were filtered and the residual concentrations of the filtrates were analyzed using atomic absorption spectrophotometer (Bulk SCIENTIFIC/ Model 210VGP). The percentage sorptions of metal ions onto soursop peel were calculated using the following expression:

$$
\% \text { removal }=\frac{\left(C_{i}-C_{f}\right)}{C_{i}} \times 100
$$

Where, $C_{i}$ and $C_{f}$ are the initial and final concentrations of the heavy metals present in wastewater before and after adsorption, in $(\mathrm{mg} / \mathrm{L})$ respectively.

The mass balance equation was used to determine the adsorption capacity $q_{e}$ from the equation:

$$
\mathrm{q}_{\mathrm{e}}=\frac{\left(\mathrm{C}_{\mathrm{i}-} \mathrm{C}_{\mathrm{e}}\right) \mathrm{V}}{\mathrm{m}}
$$

The amount of metal ions adsorbed by the adsorbent was evaluated using equation:

$$
\mathrm{q}_{\mathrm{t}}=\frac{\left(\mathrm{C}_{\left.\mathrm{i}-\mathrm{C}_{\mathrm{t}}\right) \mathrm{v}}\right.}{\mathrm{m}}
$$

Where $C_{i}$ is initial concentration of metal ions in the solution $\left(\mathrm{mgdm}^{-3}\right), \mathrm{C}_{\mathrm{e}}$ is the equilibrium concentration or initial concentration of metal ions in the solution $\left(\mathrm{mgdm}^{-3}\right), \mathrm{V}$ is the initial volume of metal ion solution used $\left(\mathrm{dm}^{3}\right)$ and $\mathrm{m}$ is the mass of adsorbent $(\mathrm{g})$.

\subsection{Sorption Kinetics}

\subsubsection{Pseudo First-Order Kinetic Model}

The pseudo first-order kinetic model was applied to the experimental data to describe the kinetics of metal ions sorption. Using the equation given below:

$$
\ln \left(q_{e}-q_{t}\right)=\ln q_{e}-\mathrm{k}_{1} \mathrm{t}
$$

Where $q_{t}$ and $q_{e}$ are the amounts of solute sorbed per mass of sorbent $(\mathrm{mg} / \mathrm{g})$ at any time and equilibrium, respectively, and $\mathrm{k}_{1}$ is the rate constant of first-order sorption $\left(\mathrm{min}^{-1}\right)$. Hence the amount of solute sorbed per gramme of sorbent at equilibrium $\left(q_{e}\right)$ and the first-order sorption rate constant $\left(\mathrm{k}_{1}\right)$ was evaluated from the slope and the intercept.

\subsubsection{Pseudo Second-Order Kinetic Model}

The pseudo second-order kinetic model was applied to the experimental data to describe the kinetics of metal ions sorption. The model is represented as:

$$
\frac{\mathrm{t}}{\mathrm{q}_{\mathrm{t}}}=\frac{1}{\mathrm{k}_{2} \mathrm{q}_{\mathrm{e}}^{2}}+\frac{\mathrm{t}}{\mathrm{q}_{\mathrm{e}}}
$$

Where $\mathrm{k}_{2}$ is the second-order reaction rate equilibrium constant $(\mathrm{g} / \mathrm{mg} \min )$. A plot of $\frac{\mathrm{t}}{\mathrm{q}_{\mathrm{t}}}$ against $\mathrm{t}$ giving a linear relationship was employed for the applicability of the second-order kinetic.

\subsubsection{Elovich Kinetic Equation}

The Elovich kinetic equation given as:

$$
q_{t}=\ln \mathrm{a}+\mathrm{blnt}
$$

Where $\alpha(\mathrm{mg} / \mathrm{g} \cdot \mathrm{min})$ is the initial biosorption rate and $\beta$ ( $\mathrm{g} / \mathrm{mg}$ ) the desorption constant related to the extent of surface coverage and activation energy for chemisorptions was examined for this study. A lot of $q_{t}$ versus lntwhich gave a linear plot was taken for the applicability Elovich kinetic in this study.

\section{Results and Discussion}

\subsection{Effects of Contact Time on Adsorption Process}

The relationship between contact time and the percentage removal of $\mathrm{Pb}, \mathrm{Cd}$ and $\mathrm{Co}$ ions from wastewater with soursop peel is shown in Figure 2. The effect of contact time was studied at room temperature of $32^{\circ} \mathrm{C}$, at an interval of 30 minutes. From the results obtained, it was observed that as 
the contact time increased, the amount of metal ion adsorbed increased. Equilibrium was reached within 30 minutes for both $\mathrm{Cd}$ (II) and $\mathrm{Co}$ (II) ions and 60 minutes for $\mathrm{Pb}$ (II) ions. The maximum percentages of metal ions removal of the ions were $78.43,65.22$ and $88.75 \%$ for $\mathrm{Cd}(\mathrm{II}), \mathrm{Co}(\mathrm{II})$ and $\mathrm{Pb}(\mathrm{II})$ ions respectively with the corresponding adsorptive capacities of $0.032 \mathrm{mg} / \mathrm{g}, \quad 0.212 \mathrm{mg} / \mathrm{g}$ and $0.057 \mathrm{mg} / \mathrm{g}$ respectively. This trend $\mathrm{Pb}$ (II) $>\mathrm{Cd}$ (II) $>\mathrm{Co}$ (II) ions was observed, after which further increase in time did not bring about any further increment for the metal ions but resulted in the desorption of some of the metal ions from the adsorbent surface. A similar trend was reported by Bernard et al. [11]. This observation could possibly be as a result of different in ionic radii. The ionic radius of $\mathrm{Pb}$ is $1.33 \AA$ followed by that of cadmium $(0.95 \AA)$ while that of cobalt is $0.75 \AA$ Also, sterric hinderance could be used to explain the adsorption of these ions. The sterric hinderance resulting from the size of the hydrated lead ions is the greatest followed by that of $\mathrm{Cd}(\mathrm{II})$ ions while that of $\mathrm{Co}$ (II) is the least.

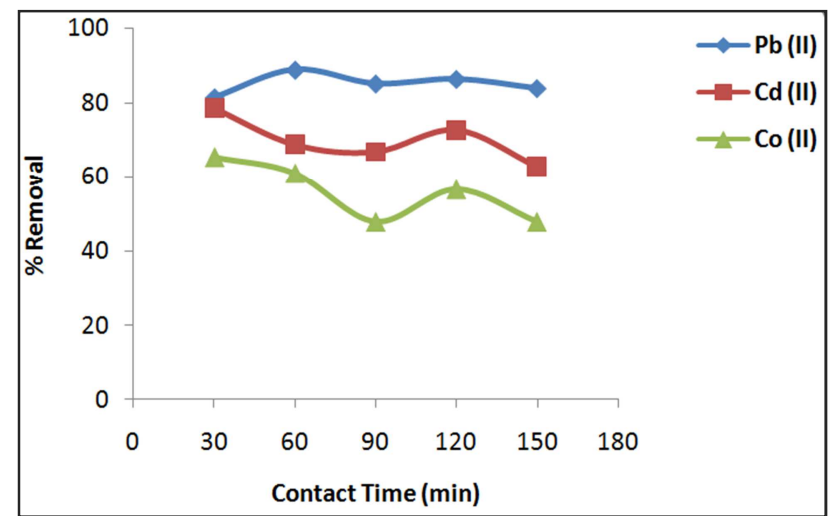

Figure 1. The effect of contact time on the adsorption of $\mathrm{Pb}, \mathrm{Cd}$ and Co ions by soursop (Annonamuricata) peel.

\subsection{Effects of $\mathrm{pH}$}

$\mathrm{pH}$ is one of the key factors to be considered in the process of adsorption of metal ions from wastewater due to the fact that it accounts for the protonation of metal binding sites. It was found that removal of $\mathrm{Pb}$ (II), Cd (II) and Co (II) ions by soursop peel was $\mathrm{pH}$ dependent as shown in Figure 2. At lower $\mathrm{pH}$ values, the metal $(\mathrm{Pb}, \mathrm{Cd}$ and $\mathrm{Co})$ ions were poorly adsorbed, this is probably as a result of the competition between the metal ions and the hydrogen ion of the same active sorption sites with obvious dominance of hydrogen ions which resist the advance of metal cation as a result of repulsive forces. As $\mathrm{pH}$ increased between 3 and 4, the hydroxonium ions were getting deprotonated and more of metal ion was removed. The maximum uptake was observed when the $\mathrm{pH}$ increased to 4 for Co (II) ions which may be attributed to binding. Reduction in Co (II) ions adsorbed can therefore be related to the nature of ion pairs involving the dominant anion in the system [12].

As the $\mathrm{pH}$ increases from 4 to 5 , the functional group of the absorbent was exposed. This increased the negative density charge on the surface of the absorbent and therefore increases the electrostatic attraction and the desirability of the metallic ions with the positive charge by the adsorbent leading to a higher chance of adsorption on the adsorbent surface. This means that at higher hydrogen ion $\left(\mathrm{H}^{+}\right)$ concentration, the surface inhibits the interaction between the adsorbent and the metal ion, thus, as the $\mathrm{pH}$ increases, the binding sites starts deprotonating thus making available site for more uptake of the metal ions. This continues to $\mathrm{pH} 6$ for $\mathrm{Pb}$ (II) and $\mathrm{Cd}$ (II) ions. Similar results were obtained on akee apple pod by Jimoh et al [10]. However, at $\mathrm{pH}$ higher than 6 , the adsorption of the metal ions decreased as a result of decrease in the degree of protonation of the functional groups of the adsorbent [13].

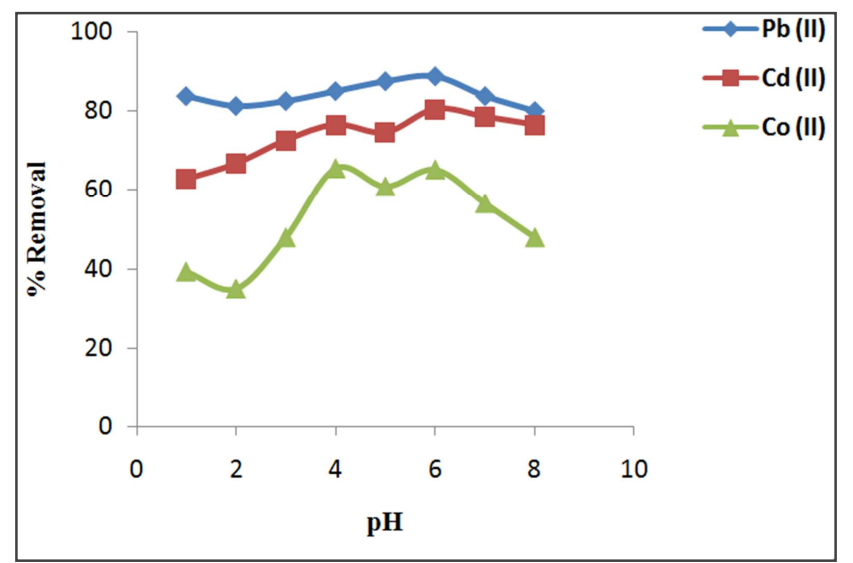

Figure 2. The effect of $\mathrm{pH}$ on the adsorption of $\mathrm{Pb}, \mathrm{Cd}$ and $\mathrm{Co}$ ions by soursop (Annonamuricata) peel.

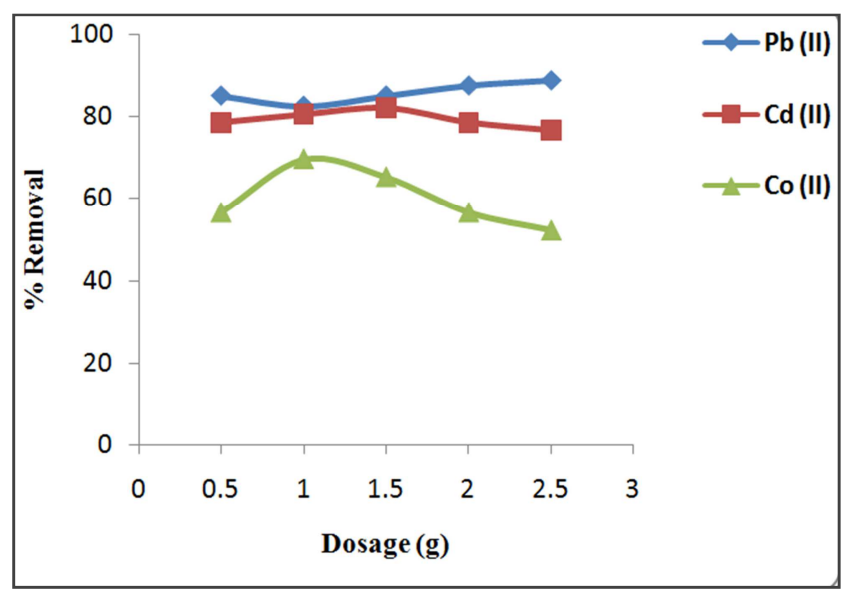

Figure 3. The effect of dosage on the adsorption of $\mathrm{Pb}, \mathrm{Cd}$ and $\mathrm{Co}$ ions soursop (Annonamurica) peel.

\subsection{Effects of Adsorbent Dosage on Adsorption Process}

The adsorption of $\mathrm{Pb}, \mathrm{Cd}$ and $\mathrm{Co}$ (II) ions onto soursop peel was studied by changing the adsorbent dosage in the test solution while keeping other parameters constant. Increase in adsorbent dosage led to a corresponding increase in percentage removal of the metal ions as shown in Figure 3. This is due to an increase in surface area of the adsorbent [14]. At high dose, $\mathrm{Pb}$ (II) ions were efficiently adsorbed with the highest percentage removal of $88.76 \%$ at a dose of 
$2.5 \mathrm{~g}$. This could be attributed to the availability of free surface charges on the binding sites and increase in the adsorbent surface area. However, at a dose of $1.5 \mathrm{~g}$ and $1.0 \mathrm{~g}$ for $\mathrm{Cd}$ and $\mathrm{Co}$ ion respectively, adsorption decreased. This might have been as a result of the very fast superficial adsorption onto the adsorbent surface that produces a lower solute concentration in the solution at low when adsorbent dose. Thus with an increase in adsorbent dose, the amount of $\mathrm{Cd}$ and Co metal ions adsorbed per unit mass of adsorbent is reduced. This in turn causes a decrease in equilibrium uptake value. The maximum uptake of these ions were found to be $88.76,82.00$ and $69.56 \%$ for $\mathrm{Pb}(\mathrm{II}), \mathrm{Cd}(\mathrm{II})$ and $\mathrm{Co}(\mathrm{II})$ ins respectively.

\subsection{Effect of Particle Size}

The effect of variation of particle size on the adsorption is shown in Figure 4. According to Krishna and Swamy [15] the breaking up of larger particles to form smaller ones opens some tiny sealed channels that will be available for adsorption and therefore the rate of uptake by smaller particles is higher than that by larger particles. It could be inferred from Figure 4 that increase in particle size decreased the percentage removal. At a fixed adsorbent dosage, decrease in particle size increased the amount of metal uptake. The increase in the uptake by smaller particles was due to the greater accessibility to pores and to greater surface area of the bulk adsorption by mass of the adsorbent.

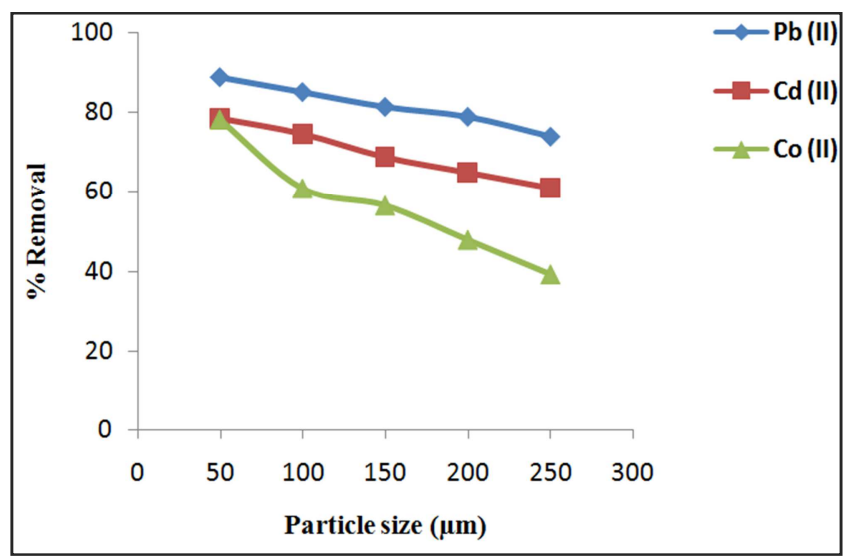

Figure 4. The effect of particle size on the adsorption of $\mathrm{Pb}, \mathrm{Cd}$ and Co ions by soursop (Annonamuricata) peel.

\subsection{Kinetic Study}

Several kinetic models are needed to establish the mechanism of a biosorption process. In order to investigate the kinetics of the biosorption of these metal ions on soursop peel, three kinetic models were employed. These are the pseudo-first order, pseudo-second order and the Elovich equations. In the three metal ions under study, the plot of $\frac{t}{q_{t}}$ against $t$ showed good fitness, efficiency and applicability of experimental data with pseudo-second order kinetic model as shown in below. The correlation coefficients were found to be highest for the pseudo-second order kinetic model as shown in Table 1. On comparison of the values of $\mathrm{R}^{2}$ for the experimental points, the pseudo-second order kinetic model is the best kinetic model for the predict ion of the dynamic biosorption of $\mathrm{Pb}, \mathrm{Cd}$, and $\mathrm{Co}$ metal ions onto soursop peel. The correlation coefficients $\left(\mathrm{R}^{2}\right)$ values for $\mathrm{Pb}, \mathrm{Cd}$, and $\mathrm{Co}$ ions are $0.998,0.984$ and 0.974 respectively. The results shows that the rate of biosorption of the metal ions is of the order $\mathrm{Pb}>\mathrm{Cd}>\mathrm{Co}$ which may be due to the differences in the hydrated ionic sizes of the ions in the solution [16]. The higher ionic radius of lead $(\mathrm{Pb})$ is definitely responsible for its fastest rate of biosorption to the soursop peel. The biosorption capacity of this biosorbent for these ions is in the order $\mathrm{Co}>\mathrm{Pb}>\mathrm{Cd}$. This implies that the amount of each metal biosorbed depends on its valency.

Table 1. Kinetics rate model for the sorption of lead, cadmium and cobalt ions by soursop peel.

\begin{tabular}{lllll}
\hline Kinetic & Parameter & Pb & Cd & Co \\
\hline Pseudo-first-order & $K_{1}\left(\mathrm{~min}^{-1}\right)$ & 0.023 & 0.035 & 0.035 \\
& $q_{e}(\mathrm{mg} / \mathrm{g})$ & 0.081 & 0.300 & 0.170 \\
& $R^{2}$ & 0.191 & 0.458 & 0.356 \\
Pseudo-second-order & $K_{2}(\mathrm{~g} / \mathrm{mg} / \mathrm{min})$ & 20.27 & 5.762 & 11.070 \\
& $q_{e}(\mathrm{mg} / \mathrm{g})$ & 0.054 & 0.026 & 0.0085 \\
& $R^{2}$ & 0.998 & 0.984 & 0.974 \\
Elovich & $a$ & 0.05 & 0.041 & 0.018 \\
& $b$ & 0.001 & 0.003 & -0.001 \\
& $R^{2}$ & 0.120 & 0.604 & 0.685 \\
\hline
\end{tabular}

\section{Conclusion}

The present investigation shows that the soursop (Annonamuricata) peel can be employed as a potentially low cost sorbent for the removal of $\mathrm{Pb}, \mathrm{Cd}$, and $\mathrm{Co}$ ions from oil spill water. The adsorption of $\mathrm{Pb}, \mathrm{Cd}$, and $\mathrm{Co}$ ions was found to be greatly dependent on the effect of $\mathrm{pH}$ of the solution, contact time, adsorbent dosage and particle size. The maximum biosorption of the metal ions was between $\mathrm{pH}$ values of 4 and 6 . The kinetic experiments showed that pseudo-second-order reaction model best described the adsorption process. These results show that the adsorbent appears to be technically feasible, user-friendly and ecofriendly.

\section{References}

[1] Kingston, P. F. (2002). Long-term environmental impact of oil spills. Spill Science and Technology Bulletin, 7 (1-2): 53-61.

[2] Burgherr, P. (2006). In-depth analysis of accidental oil spills from tankers in the context of global spill trends from all sources. Journal of Hazardous Materials, 40: 245 -256.

[3] Centre for Environment, Human Rights and Development (CEHRD). 2008. Persistent Oil Spillage at Bodo Creek; Unprecedented Impacts on Ecosystem Stability, Biodiversity and Food Security of Ogoni Communities. www.cehrd.org/files/BODO_OIL_SPILL.doc.

[4] Amnesty International. (2009). Petroleum, Pollution and Poverty in the Niger Delta. http://www.amnesty.org/en/library/. 
[5] Kanu, ijeoma and Achi, O. K. (2011). Industrial effluents and their impact on water quality of receiving rivers in Nigeria. Journal of Applied Technology in Environmental Sanitation, 1 (1): 75-86.

[6] Ogaji, S. O. T., M. J. Ayotamuno, R. B. Kogbara and S. D. Probert, (2005). Bioremediation ofa Crude Oil Polluted Agricultural Soil at Port-Harcourt, Nigeria. School Engineering, Cranfield University, Bedfordshire, UK.

[7] Moussavi, G. and B. Barikbin, (2010). "Biosorption of Chromium (VI) from Industrial Wastewater on to Pistachio Hull Waste Biomass." Chem. Engg. J., 62: 893-900.

[8] Ideriah, T. J. K., David, O. D. and Ogbonna, D. N. (2012). Removal of heavy metal ions in aqueous solutions using palm fruit fibre as adsorbent. J. Environ. Chem. Ecotoxicol. 4(4): $82-90$.

[9] Kumar, U. 2006. Agricultural products and by-products as a low cost adsorbent for heavy metal removal from water and wastewater: A review. Scientific Research and Essay 1(2): 33-7.

[10] Jimoh, T. O., Buoro, A. T. and Muriana, M. (2012). Utilization of Blighiasapida (Akee apple) pod in removal of lead, cadmium and cobalt ions from aqueous solution. J. Environ. Chem. Ecotoxicol 4(10): 178-187.

[11] Bernard, E., Jimoh, A., and Odigure, J. O., (2013). Heavy metals removal from industrial waste Water by activated carbon prepared from coconut shell. Res. J. Of Chem. Sci. 3(8): 3-9.
[12] Payne, T., Itakura, T., Comarmorol, M., and Harrison, J. (2009). Environmental mobility of cobalt influence of solid phase characteristics and ground water chemistry. Proc. From the $6^{\text {th }}$ int. conf. on isotopes. Appl. Radiation Isotopes. 67 (78): $1269-1276$.

[13] Saima, Q. M., Jamal, R. M., Bhanger, M. I., Zuhra, G. M., ElTurki, A., Geoffrey, C. A. (2008). Characterization of banana peel by scanning electron microscopy and FT-I spectroscopy and its use for cadmium removal. Colloids surf. Biointerfaces 66 (2): 260-265.

[14] Gborbami, M., H. Eisazadeh, and A. A. Ghoreyishi. (2012). Removal of zinc ions from aqueous solution using polyanilinenanocomposite coated on rice hust. Iranica journal of energy and environment. 3 (1): 83-88.

[15] Krishna, H. R and Swamy, V. V. S. (2012). Investigation on the effect of particle size and adsorption kinetic for the removal of $\mathrm{Cr}$ (VI) from the aqueous solution using low cost sorbent. Eur. Chem. Bull, 1(7), 258-262.

[16] Babarinde N. A. Adesola, Oyebamiji Babalola, J., John Adegoke, Uchechi Maraizu, Temitope Ogunbawo and Fopefoluwa Ogunjinrin. (2012). Kinetic equilibrium and thermodynamic studies of the biosorption of $\mathrm{Ni}$ (II), $\mathrm{Cr}$ (III), and Co (II) from aqueous solutions using banana (Musa acuminata) leaf. Int. J. Phys. Sc.7 (9): 1376-1385. 